\title{
SVETLEJŠA PRIHODNOST SLOVENSKE REGIONALNE GEOGRAFIJE?
}

\author{
dr. Mirko Pak \\ Pod vrbami I, SI-I000 Ljubljana \\ e-mail: mirko.pak@guest.arnes.si
}

Pregledni znanstveni članek

COBISS 1.02

\section{Izvleček}

Z geografskimi monografijami Slovenije A. Melika ter univerzitetnimi in srednješolskimi učbeniki S. Ilešiča je slovenska regionalna geografija sledila mednarodnim dosežkom na tem področju. Po burnih razpravah o metodologiji in o pomenu regionalne geografije se zanimanje zanjo v Sloveniji povečuje v znanosti, izobraževanju in praksi.

Ključne besede: regionalna geografija, razvoj, Slovenija

\section{A BRIGHTER FUTURE OF THE SLOVENE REGIONAL GEOGRAPHY?}

\begin{abstract}
Geographical monographs of Slovenia by A. Melik, and university and secondary school textbooks by S. Ilešič, enabled the Slovene regional geography to pursue international developments in this field. Tempestuous debates about the methodology and meaning of Slovene regional geography were followed by an increased interest for this matter in science, education and in practice.
\end{abstract}

Key words: regional geography, development, Slovenia 


\section{POL STOLETJA SLOVENSKE REGIONALNE GEOGRAFIJE}

Že skoraj polstoletne dileme o vsebinski in morda še bolj o metodološki primernosti regionalnogeografskih prizadevanj v Sloveniji so, ob podobnih pomislekih tudi v tujih geografskih sredinah, spremljale številne, v slovenski geografiji že velikokrat omenjane razprave. Posebej izčrpno pa so bile predstavljene ob življenjskih jubilejih obeh velikih slovenskih geografov Antona Melika (Ilešič 1960) in Svetozarja Ilešiča (Vrišer 1985) ter ob obletnicah Oddelka za geografijo Filozofske fakultete v Ljubljani. Polemike o predmetu, vsebini in metodah regionalne geografije, še posebej za potrebe izobraževanja, so se razmahnile v sedemdesetih letih prejšnjega stoletja z razmišljanji o njeni vsebinski in metodološki modernizaciji (Gams 1974, 1977; Medved 1973; Ilešič 1974). Oddelek za geografijo Filozofske fakultete v Ljubljani je organiziral na to temo tudi nekaj znanstvenih srečanj, med katerimi je po svoji širini vsekakor izstopal jugoslovanski simpozij z naslovom Teorija in metodologija regionalne geografije (Pak 1987), na katerem so med drugimi sodelovali kar številni univerzitetni profesorji, večinoma tudi pisci regionalnogeografskih visokošolskih učbenikov iz vseh jugoslovanskih geografskih središč. Na tem mestu se mi zdi potrebno vsaj opozoriti na morda premalo izpostavljeno, znamenito in še danes aktualno Ilešičevo knjigo Pogledi na geografijo, zbirko njegovih najbolj znanih študij o geografiji, predvsem o njeni teoretski problematiki ter o regionalizaciji kot elementu regionalne geografije (1979). Pozoren bralec bo v knjigi našel argumentirane odgovore tudi na večino vprašanj in dilem v zvezi z regionalno geografijo, ki so se v kasnejših tovrstnih razpravljanjih bolj ali manj ponavljala.

Naša nedvomno najbolj plodna pisca regionalnogeografskih del, A. Melik in S. Ilešič, sta svoje obsežno delo na regionalnogeografskem področju uskladila s potrebami visokošolskega študija. Melikovi obsežni regionalnogeografski orisi Slovenije (Slovenski alpski svet 1954, Štajerska s Prekmurjem in Mežiško dolino 1957, Posavska Slovenija 1959, Slovensko primorje 1960 in seveda tudi Slovenija I - geografski opis 1935-36 in 1963) in Jugoslavije (1948) ter Ilešičevi visokošolski učbeniki Amerika (1952), Afrika, Južna Azija, Avstralija z Oceanijo in južnim polarnim svetom (1957), Gospodarska in politična geografija sveta, ki je izšla kar sedemkrat $(1947,1952,1959,1960,1962,1964,1966)$, ter še posebej njegova Geografija Evrope s Sovjetsko zvezo (1966), pri čemer je S. Ilešič pozneje napisal še vrsto gimnazijskih učbenikov (mdr. 1969; 1973; 1975), ki so še dolgo služili svojemu namenu (Lovrenčak 1987). Večkrat so bili ponatisnjeni tudi v srbohrvaškem jeziku, po svoji kvaliteti pa niso zaostajali za tujimi učbeniki. Ob tem se v celoti kaže pridružiti Vrišerjevi oceni, da je bil Ilešič nedosegljiv mojster v geografski metodiki, nazornosti, razumljivosti, jasnosti izražanja in načinu pisanja (Vrišer 1985).

Poizkusi, zlasti metodološko 'moderniziranih' srednješolskih učbenikov ob uvajanju usmerjenega izobraževanja, niso izpolnili pričakovanj, kar velja tudi za oba univerzitetnemu študiju geografije namenjena učbenika Afrike (1969) in Azije (1972). To pa ni bil samo čas živahnih poizkusov metodološko-vsebinske modernizacije regionalne geografije kot take, ki se je s podobnimi problemi soočala tudi drugod po svetu. To je bil tudi čas hitrejšega družbenega in gospodarskega napredka in razvoja, radikalnih prostorskih sprememb in razvoja geografske stroke. Vse to je tudi slovenske geografe vodilo v vedno močnejšo specializacijo v stroki sami ter na posameznih področjih fizične in družbene geografije. Slovensko geografijo, ki je 
v svojem raziskovalnem delu kar uspešno sledila evropskim razvojnim trendom v geografiji, so vedno bolj privlačevali aktualni prostorski problemi in procesi. V to jih je silila tudi praksa sama, kar se je že v šestdesetih letih prejšnjega stoletja manifestiralo s sodelovanjem v raziskavah za potrebe regionalnega planiranja in v regionalnem planiranju samem. Večdesetletna vodilna vloga geografije na tem področju (I. Vrišer, V. Kokole, V. Klemenčič, M. Jeršič in drugi) je z doslednim prizadevanjem za decentraliziran regionalni razvoj Slovenije veliko prispevala k njenemu skladnejšemu regionalnemu razvoju in namenila nemalo zanimanja tudi razvojnim problemom odročnih, obrobnih in obmejnih območij. Če se danes brez nekdanje dualistične obremenjenosti ozremo na ta prizadevanja, jim lahko upravičeno priznamo značaj moderne aplikativne regionalne geografije.

To pa je močno ali celo odločilno vplivalo tako na raziskovalno kot na kompilativno regionalno geografijo. Z ustanovitvijo Inštituta za geografijo Univerze v Ljubljani leta 1961 so predvsem sodelavci Oddelka za geografijo in inštituta v okviru svojih doktorskih disertacij opravili na Oddelku za geografijo pod mentorstvom S. Ilešiča in V. Klemenčiča vrsto problemsko usmerjenih regionalnogeografskih raziskav slovenskih pokrajin (Koprsko primorje, Vinorodne Haloze, Ormoško-Ljutomerske gorice, Zgornje Dravsko polje, Ptujsko polje, Gozdnate Haloze, Mežiška dolina, Bohinj, Bled, Škofja Loka, Ljubljansko barje, Kozjansko). Te analitskosintetične in kompleksne študije razvojnih elementov in procesov so še danes aktualne in temeljne za razumevanje najnovejših regionalno-razvojnih procesov v izredno raznolikih slovenskih pokrajinah. Kompleksno, regionalno in problemsko, so slovenski geografi preučevali in razvojno vrednotili vseskozi in še posebej v sedanjem času gospodarskih in socialnih pretresov tudi Prekmurje, eno najbolj samosvojih in razvojno prizadetih slovenskih regij. Prekmurje se tega še do danes ni otreslo, kar so potrdile tudi študije, ki so bile opravljene za zborovanje slovenskih geografov leta 2008 in so objavljene v posebnem zborniku Pomurje - geografski pogledi na pokrajino ob Muri (2009). Podobne bolj ali manj kompleksne raziskave slovenskih pokrajin smo dobili ob vseh zborovanjih slovenskih geografov. Med njimi kaže posebej izpostaviti enega največjih slovenskih raziskovalnih projektov ob zborovanju slovenskih geografov na Ptuju leta 1996, katerega rezultati so bili objavljeni v obsežnem zborniku Spodnje Podravje s Prlekijo (1996).

Tako zelo plodna slovenska regionalna geografija četrt stoletja po drugi svetovni vojni, po obsegu kot v metodološkem pogledu v glavnem ni zaostajala za tujimi prizadevanji. Zlasti v slednjem je znatno prednjačila pred drugimi jugoslovanskimi geografskimi središči. Ostale pa so nerešene dileme v zvezi z njeno modernizacijo, 'uravnoteženim' podajanjem naravnih in družbenogeografskih dejavnikov v njihovi soodvisnosti, v specializaciji oziroma usmeritvi, v njeni aplikaciji in uporabnosti.

\section{PRELOMNO OBDOBJE SLOVENSKE REGIONALNE GEOGRAFIJE}

Ne glede na to, da se je tudi v slovenski geografiji krepila specializacija, se potreba po sami regionalni geografiji in po njeni modernizaciji ni zmanjšala, kljub izpostavljanju njene krize in njene potrebnosti, oziroma koristnosti. Ob vedno boljših možnostih računalniške tehnike pridobivanja informacij o regionalnogeografskih vsebinah, pa nagel družbeno-gospodarski 
razvoj terja vedno bolj kompleksno poznavanje, obravnavo, reševanje in predstavljanje regionalno-prostorske problematike. Ekološki problemi, gospodarska kriza, politične spremembe in s tem povezane družbeno-gospodarske spremembe, vključno $\mathrm{z}$ globalizacijo, to še potrjujejo. Na te zahteve se je tudi slovenska regionalna geografija dokaj hitro odzvala, tako pri monografskih prikazih, na raziskovalnem in na aplikativnem področju ter pri izobraževanju.

Kljub večkratnim spremembam študijskih programov na Oddelku za geografijo Filozofske fakultete v Ljubljani, ki so do leta 1986 prikazane v šesti številki revije Dela (Pak 1989), se je delež ur regionalnogeografskih predmetov vključno s predavanji, vajami, seminarji in terenskimi vajami, konstantno gibal med 25 in $40 \%$. Dileme o obsegu ter smotrnosti takšnega ali drugačnega študija regionalne geografije na univerzi, ki so se vedno bolj prenašale tudi na vprašanja regionalne geografije v srednji, pa tudi v osnovni šoli, Gams povezuje z zastopanostjo regionalnogeografskih predmetov v teh učnih načrtih (Gams 1987). Vendar tudi najnovejši, na bolonjskih izhodiščih zasnovani študijski programi, v glavnem ohranjajo regionalnogeografskim vsebinam dosedanjo veljavo, seveda bolj selektivno kot doslej v pogledu izbirnosti, samem številu predmetov in njihovi vsebinski zasnovi. Danes ni več dvoma, da potreba po regionalnogeografskih vsebinah na splošno narašča, pa tudi potreba po prenosu sodobnega regionalnogeografskega koncepta na vsa geografska področja (Plut 1989). Ob tem je bila, zaradi svojega kompleksnega pristopa, kar vrsta splošnih geografskih predmetov opredeljena za regionalnogeografske: varstvo okolja, geografija podeželja, geografija krasa, geografija naravnih nesreč. Kompetentnost takšne opredelitve, kakor tudi struktura klasičnih regionalnogeografskih predmetov, pa je seveda odvisna predvsem od strokovne usmeritve predavateljev. I. Vrišer tudi urbani geografiji pripisuje regionalnogeografski značaj, kamor verjetno res lahko štejemo mestne monografije, pa problematiko urbanizacije in suburbanizacije. Podobni so študijski predmeti in njihove vsebine tudi na drugih domačih in tujih univerzitetnih študijih, glede na namen izobraževanja $v$ pedagoških ali nepedagoških programih. Tako kot $\mathrm{v}$ tujini, je tudi v Sloveniji problem specializiranih regionalnih geografov, ki bi se primarno ukvarjali z regionalno geografijo. Izjeme se praviloma niso posebej izkazale $\mathrm{v}$ vseh elementih tega geografskega področja, še posebej ne na področju teorije in metodologije. Slednjih primerov je bilo nemalo zlasti v drugih jugoslovanskih geografskih sredinah, pa tudi drugod po svetu jih ni manjkalo.

Nove informacije in deloma tudi tehnični pogoji so že $\mathrm{v}$ šestdesetih letih prejšnjega stoletja oživili delo na regionalnogeografskem področju, sprva na prvih povojnih nacionalnih geografskih atlasih. Tako se je, tudi za potrebe organiziranega raziskovalnega dela oddelčnih sodelavcev leta 1961 ustanovljeni Inštitut za geografijo Univerze v Ljubljani, že leta 1965 lotil priprave Nacionalnega atlasa Slovenije, ki naj bi na kartah v osnovnem merilu $1: 400.000$ in v večjih merilih, na okrog 100 listih predstavil vse relevantne vsebine regionalne podobe Slovenije, z ustreznimi spremljevalnimi teksti. V izdelavo tega, za takratni čas izjemno zahtevnega projekta, je vodstvo projekta, ki je bilo pretežno v rokah sodelavcev Oddelka za geografijo, vključilo najvidnejše geografe in druge strokovnjake za posamezna strokovna področja. Ko so bile po desetih letih, v sodelovanju z Geodetskim zavodom Slovenije poskusno tiskane prve štiri karte in ko je bila tudi že skoraj polovica vseh kart pripravljena za tisk, projekta iz subjektivnih in objektivnih razlogov ni bilo moč izpeljati do konca. Med vzroki 
nedokončanosti so izstopali finance, stopnja neraziskanosti posameznih elementov ter sam tehnološki razvoj priprave tiskarskih originalov in s tem povezane zamude ter zastarelost podatkov. Še kaj bi bilo mogoče našteti, kar je onemogočilo nadaljevanje dela na do takrat največjem geografskem projektu pri nas.

Podobno se je dogajalo z drugim velikim vseslovenskim regionalnogeografskim raziskovalnim projektom Regionalnogeografska monografija Slovenije, ki ga je vodil Geografski inštitut Antona Melika ZRC SAZU. Njeno vsebinsko zasnovo je leta 1974 v Geografskem vestniku predstavil S. Ilešič (1974), ki je ob krajšem uvodnem poglavju predvidel obravnavo po makroregijah, podrobnejša obdelava pa bi bila po mezoregijah in po potrebi tudi po submezo- in mikroregijah. Obravnave štirih makroregij so se lotili oba univerzitetna oddelka za geografijo v Ljubljani in Mariboru, Geografski inštitut Antona Melika ZRC SAZU ter Inštitut za geografijo Univerze v Ljubljani. Težave večletnega raziskovalnega projekta, v katerega je bilo vključenih nad 100 sodelavcev, so bile predvsem metodološka neusklajenost na ravni piscev posameznih regionalnih enot, deloma tudi na ravni makroregij in $\mathrm{s}$ tem povezane zamude, zaradi česar projekta na zamišljeni način ni bilo mogoče zaključiti. Zato je Geografski institut Antona Melika ZRC SAZU, s sodelovanjem urednikov posameznih makroregij ter nekaterih drugih zunanjih sodelavcev in svojih mlajših raziskovalcev, pripravljeno gradivo priredil v enoten tekst za 53 pokrajin. Tako je namesto težko pričakovane moderne znanstvene monografije slovenskih regij leta 1998 na 735 straneh izšla strokovna monografija Slovenija - pokrajine in ljudje. Obsežen strokovni tekst s 450 slikami, 100 zemljevidi in 600 grafikoni je sicer kvalitetno in korektno strokovno delo, ki pa Melikove Slovenije $\mathrm{v}$ znanstvenem in metodološkem pogledu ni preseglo in nadgradilo. Ponovno pa je pokazalo na skromno zanimanje in na različne poglede slovenskih geografov za tovrstna regionalnogeografska prizadevanja ter na razlike v metodoloških pogledih. Pri večini avtorjev posameznih pokrajinskih enot je namreč jasno izstopala piščeva osnovna strokovna usmeritev.

Namerno daljši zapis o atlasu in o monografiji Slovenije kaže na objektivni položaj v slovenski regionalni geografiji, ki je sicer dokaj plodna, a z metodološko marsikdaj zelo subjektivnimi pogledi. D. Plut (1989) verjetno pravilno ugotavlja, da je v zadnjih tridesetih letih vendarle tudi več prizadevanj k reintegraciji geografije in prenosu sodobnega regionalnogeografskega koncepta v vse geografske sfere, pri čemer je združevanje vseh treh komponent, fizične, socialne (družbene, opomba avtorja) in regionalne, kot ga uporaba sodobnih računalniških tehnik omogoča, še vedno redko in nedosledno. Ob tem se je pojem regionalne geografije raztegnil na že našteta druga specializirana geografska področja. Temu sledi tudi definicija regionalne geografije v Geografskem terminološkem slovarju, ki pravi, da je regionalna geografija »temeljni del geografije, ki z metodo kompleksne geografije ali povezovanjem, prepletanjem posameznih geografskih panog sintetično obravnava Zemljino površje ali njegove posamezne dele« $(2005,337)$, kar kaže na širjenje regionalnogeografskega koncepta.

V šestdesetih letih prejšnjega stoletja opredeljeno problemsko regionalno geografijo argumentirano zagovarja S. Ilešič v svoji študiji Metodološki problemi sodobne geografije (Ilešič 1979). Problemska usmeritev pa je lahko tudi pogojena z namenom, oziroma uporabnostjo, značajem študije. In ker je tudi v Sloveniji slednjih študij vedno več v okviru var- 
stva okolja, naravnih nesreč, podeželja, urbanizacije itd., so močno usmerjene v temeljno vsebino razprave. Zato bi bilo v tem pomenu bolje govoriti o regionalnogeografskem konceptu kot o regionalnih študijah. Ali bi v nasprotnem splošnogeografskim predmetom sploh še kaj ostalo? Za regionalnogeografska dela je ena temeljnih zahtev kompleksnost, kar ne pomeni le navajanje raznih razvojnih dejavnikov (statične regije ni), ampak njihovo součinkovanje. Nova tehnologija, še posebej pa večja dosegljivost podatkov in informacij, omogočajo hitrejše delo, povečanje števila obravnavanih elementov itd. Ob tem pa ni odveč opozoriti na nujnost dobrega neposrednega poznavanja predmeta raziskave (regije) ter problemskega prepletanja ali součinkovanja elementov, problemov in procesov. To pa zahteva tudi terensko delo, ki je v slovenski geografiji še vedno ustrezno prisotno in se ga pri univerzitetnem študiju geografije tudi uvaja v ustreznem obsegu, vsebini in obliki.

Zanimanje za regionalnogeografske raziskave v devetdesetih letih prejšnjega stoletja je, podobno kot drugod, tudi v Sloveniji omogočil razvoj računalniške tehnologije in opreme, s tem povezana skoraj neomejena uporaba podatkov in informacij, izdelava kompleksnih kart in drugega. Ob tem se je regionalnogeografski koncept kompleksnosti razširil na različna geografska področja. Diplomske, magistrske in doktorske naloge na vseh treh univerzitetnih oddelkih za geografijo so mlajši učitelji usmerili v bolj kompleksne raziskovalne naloge, še posebej na področju varstva okolja, geografije podeželja in regionalnega planiranja. V seznamu opravljenih tovrstnih nalog na Oddelku za geografijo FF v Ljubljani, ki so že vrsto let objavljeni v Geografskem obzorniku, najdemo tudi povsem regionalnogeografske naslove. Žal kvalitetne tovrstne regionalne analize (regionalno analizo že S. Ilešič uvršča med regionalnogeografska dela in jo v geografskih terminologijah posebej omenjene ne najdemo) le redko zaidejo tudi v geografska glasila. Monografiji Maje Topole Mirnska dolina s podnaslovom Regionalna geografija porečja Mirne na Dolenjskem (Topole 1998) in Geografija občine Moravče (Topole 2003), spadata med najbolj značilne primere sodobnih regionalnogeografskih prikazov, s (pre)številnimi podatki, kartami, diagrami in tabelami. Obe skrbno izdelani regionalni analizi sta nedvomno aplikativno - ciljno usmerjeni. Ob obstoječi in bodoči nadaljnji upravni razdelitvi Slovenije lahko pričakujemo še več podobnih regionalnih analiz. Seveda se nove regionalnogeografske poti ubirajo tudi v šolski geografiji.

Med mlajšimi raziskovalci se zanimanje za regionalnogeografski koncept povečuje. Če je K. Wolf pred leti na svojem predavanju v Ljubljani izpostavljal dejavnik potrošnikov regionalnogeografskih del (Wolf 1995), stopa danes v ospredje kvaliteta tovrstnih del.

Predvsem pa kaže, da je presežena dilema o nujnosti enakomerne obravnave fizičnih in družbenih dejavnikov ter s tem v veliki meri tudi o trdno opredeljeni metodologiji. V. Drozg, tudi predavatelj regionalne geografije na Oddelku za geografijo v Mariboru ugotavlja, da je za sodobno regionalno geografijo značilen vsakič znova (za konkreten primer) opredeljen kontekst, posledica česar je specifičen nabor relevantnih elementov in specifična interpretacija obravnavane regije (Drozg 2007).

Slovenija je leta 1998 med zadnjimi v Evropi dobila Geografski atlas Slovenije-država v prostoru in času, temeljno delo o slovenskem prostoru na 360 straneh, ki so ga ob sodelovanju številnih geografov in drugih strokovnjakov pripravili in izdali Inštitut za geografijo Univerze v Ljubljani, Geografski inštitut Antona Melika ZRC SAZU in založba DZS. Vsi tematski zemljevidi so izdelani digitalno v osnovnem merilu $1: 500.000$, primerjalni podatki 
pa so za obdobje 1961-1991. Istega leta je pri Slovenski matici izšlo še tretje obsežno regionalnogeografsko delo Geografija Slovenije, ki sta jo na 501 strani z desetimi sodelavci pripravila I. Gams in I. Vrišer (1998). Opremljena je s številnimi kartami, slikami in diagrami, večinoma v črno-beli tehniki. Slovenska geografija je po skoraj polstoletnem premoru tako dobila kvalitetna regionalnogeografska dela, ki dajejo ponovno veljavo regionalni geografiji na znanstveni, aplikativni in strokovni ravni.

V prizadevanja po večji prepoznavnosti nove države se je po osamosvojitvi Slovenije vključila tudi geografija. Zlasti nekateri sodelavci ljubljanskega Oddelka za geografijo so imeli na tujih univerzah in drugih ustanovah številna predavanja (V. Klemenčič, A. Gosar, M. Pak), kjer so največkrat predstavili regionalnogeografsko podobo in zgradbo Slovenije z njenimi specifičnimi strukturami ter razvojnimi problemi. Več teh predavanj je bilo objavljenih v tujem geografskem tisku, podobno kot referati slovenskih geografov na pogostih mednarodnih znanstvenih sestankih $\mathrm{v}$ devetdesetih letih o različnih regionalno-razvojnih vprašanjih 'postsocialističnih evropskih držav'. Seveda pa je slovenska geografija v tem času na treh mednarodnih geografskih kongresih (Washington 1992, Haag 1996 in Glasgow 2004) Slovenijo predstavila tudi najširši mednarodni geografski javnosti v posebnih publikacijah. Po nekaj neuspelih poizkusih pa je v peti številki zbirke Natur - Raum - Gesellschaft, ki jo izdaja Inštitut za humano geografijo Univerze v Frankfurtu na Majni, izšla še knjiga Slowenien - Transformationen und kleinräumige Vielfalt, ki sta jo s sodelovanjem kolegov iz vseh slovenskih geografskih inštitucij uredila V. Albrecht in V. Drozg (2008). V kolikor $\mathrm{k}$ regionalnogeografskim štejemo tudi kompleksnejše predstavitve slovenskih mest, je treba izpostaviti vsaj še knjigi Maribor/Marburg - prispevki h geografiji prijateljskih mest v Sloveniji in Nemčiji (1994), ki sta jo uredila M. Pak in J. Leib, in Geografija Ljubljane (2002), ki jo je uredil M. Pak. Prvo delo je istega leta z naslovom Marburg/Maribor-Geographische Beiträge über die Partnerstädte in Deutschland und Slowenien izšlo še v dveh publikacijah v nemškem jeziku: v 126. zvezku Marburger Geographische Schriften in v 48. številki Marburger Stadtschriften zur Geschichte und Kultur.

Povečan obseg publiciranja geografskih izsledkov pomeni tudi več regionalne geografije $\mathrm{v}$ širšem pomenu. Ker je vsaka povečana aktivnost (produktivnost) posledica potreb (povpraševanja), je tudi povečanje regionalnogeografskih prizadevanj posledica potreb po kompleksnejšem poznavanju in razumevanju okoljevarstvene problematike, celostnega razvoja podeželja, urbanizacije in suburbanizacije, naravnih nesreč. Geografija kot stroka lahko daje najboljše odgovore na kompleksna prostorska (večinoma razvojna) vprašanja. Zato ni slučajno, da geografske inštitucije zadnja leta izdajajo nove publikacije, ki v prvi vrsti sicer prinašajo izsledke plodnega znanstvenoraziskovalnega dela, ob tem pa tudi vedno več regionalnogeografskih vsebin. Tako so se že obstoječim znanstvenim revijam Geografskemu vestniku, Geografskemu zborniku, ki je bil po združitvi z Geographico Slovenico preimenovan v Acta Geographica Slovenica, ter Delom pridružile še nove. Oddelek za geografijo FF v Ljubljani izdaja zbirko monografij GeograFF, ki v tretjem zvezku prinaša študijo Življenska (ne)moč obrobnih podeželskih območij Slovenije (Klemenčič, Lampič in Potočnik Slavič 2008), sedma številka zbirke Geografija Slovenije, ki jo izdaja Geografski inštitut Antona Melika ZRC SAZU, pa prinaša obsežno študijo Geografija občine Moravče (Topole 2003). Več regionalnogeografsko usmerjenih prispevkov je najti tudi v prvih petih številkah Revije 
za geografijo Oddelka za geografijo Filozofske fakultete Univerze v Mariboru. Že vrsto let tudi Geografski obzornik prinaša zelo kvalitetne regionalnogeografske orise posameznih držav, ki so jih pisci sami obiskali, oziroma prepotovali. Če k temu prištejemo še vodnike po ekskurzijah, ki jih Ljubljansko geografsko društvo izdaja vsako leto v posebni publikaciji z naslovom Vodniki Ljubljanskega geografskega društva, je jedro tistega, kar že tradicionalno sodi k regionalni geografiji in kar se z bolj ali manj kompleksnim pristopom vedno pogosteje tudi označuje za regionalno geografijo, že kar zaokroženo. Zelo uspešno pa ta opus dopolnjuje publikacija Države sveta, ki je doživela že več dopolnjenih in predelanih izdaj ter prevodov (Natek in Natek 1999, 2000, 2005, 2006).

Nemalo zanimanja je slovenska geografija namenila problematiki regionalizacije, s katero so se ukvarjali posamezni pisci od A. Melika in S. Ilešiča naprej, pa tisti, ki so se v drugi polovici prejšnjega stoletja ukvarjali s problematiko upravne členitve Slovenije, njenega regionalnega razvoja in planiranja, do najširše rabe v izobraževanju in v znanstvenoraziskovalnem delu. Ker popolnega poenotenja praktično nikoli ni bilo, je bila ob snovanju regionalne geografije Slovenije in še bolj ob snovanju Geografskega atlasa Slovenije, regionalizacija Slovenije temu prilagojena. Za različne praktične potrebe so tudi odstopanja, tako da lahko govorimo o regionalizacijah, ki niso doživele nič manj strokovne polemike kot regionalna geografija sama. V. Drozg (2004) ugotavlja, da je regionalizacija Slovenije v številnih učbenikih med seboj slabo primerljiva. Razlike je treba odpraviti in doseči vsaj minimalno poenotenje. Zato je treba razumevanje regije in regionalizacije občasno preveriti in kritično ovrednotiti.

Največji uporabnik regionalnogeografskih prikazov je izobraževanje. Zahteva po metodološki in vsebinski modernizaciji ter didaktični prenovi učbenikov je pred tridesetimi leti pripeljala do prvih poizkusnih novih učbenikov. Razširjenemu krogu piscev učbenikov, ki so dolga leta prihajali večinoma z geografskega oddelka v Ljubljani, so se kasneje priključili predvsem praktiki, zlasti pri pisanju osnovnošolskih učbenikov. Ob tem so se sčasoma z novim gradivom, vsebinskimi in tehničnimi novostmi, slovenski regionalnogeografski šolski učbeniki dvignili na visoko raven. Posamezni, zlasti novejši učbeniki, so doživeli več izdaj, nekateri tudi dopolnila in predelave, in so se zato obdržali kar precej let. Med srednješolskimi (gimnazijskimi) so takšni starejši učbenik geografije Slovenije I. Gamsa (1983) in novejši M. M. Klemenčiča in I. Lipovška (2002), starejši učbenik geografije Evrope avtorjev S. Brinovca, B. Drobnjaka, M. Paka in J. Senegačnika (1994) ter novejši avtorjev J. Senegačnika, I. Lipovška in M. Paka (2006), ter starejši učbenik geografije sveta, avtorjev S. Brinovca, M. M. Klemenčiča, F. Lovrenčaka in M. Jeršiča (1991). Prizadevanja slovenske geografije na tem področju so pripeljala tudi do prve doktorske disertacije Geografija Evrope $v$ šolskih učbenikih evropskih držav (Senegačnik 2005).

\section{REGIONALNA GEOGRAFIJA V BODOČE}

Živahna in vedno bolj v prakso usmerjena ter v mednarodne tokove vpeta znanstvenoraziskovalna dejavnost slovenske geografije je nedvomna opora večjemu zanimanju tudi za regionalno geografijo. Geografske raziskave so vedno bolj kompleksne in vedno več raziskav vključuje regionalnogeografski koncept. To še posebej velja za raziskave s področja varstva okolja, podeželja, urbanizacije in suburbanizacije, naravnih nesreč in vseh tistih 
področij, ki se neposredno lotevajo regionalno razvojne problematike. Pozornost in interes pa se je povečal tudi za temeljne regionalnogeografske analize posameznih regionalnih enot, geografskih učbenikov in drugih, širšim uporabnikom namenjenih študij. Brez zadržkov lahko ugotovimo, da je tako geografski kot tudi regionalnogeografski aktivnosti še posebej naklonjen čas živahnih političnih, družbenih, regionalno-razvojnih sprememb, globalizacije ter drugih integracijskih procesov, kakor tudi naravnih procesov, od najširših obsežnosti do lokalnih okolij. Že samo v izobraževanju bo potreba po nenehnem tolmačenju regionalnorazvojne problematike in procesov naglo naraščala.

Nedvomno se bo regionalna geografija soočala z novimi izzivi, problemi in procesi, zaradi česar bodo tudi v nadaljnjem aktualna teoretska in metodološka vprašanja. To velja tako za raziskovalno kakor za vsa področja kompilativne regionalne geografije. Najnovejši razvoj je pokazal vsebinsko širjenje ter večjo metodološko fleksibilnost na področju regionalne geografije. Več pozornosti kot doslej bo moralo biti namenjene problemom, procesom (globalizacija) ter vzročnosti. Regionalna geografija bo nedvomno bolj problemsko usmerjena kot doslej, za kar je lep primer najnovejša, vsestranskim uporabnikom namenjena publikacija Bela krajina in Krajinski park Lahinja, ki sta jo izdala Znanstvena založba in Oddelek za geografijo ljubljanske Filozofske fakultete (2008).

Nove upravne spremembe v Sloveniji bodo nedvomno spremljali tudi razni regionalnogeografski prikazi in analize. Razvoj računalniških metod omogoča vedno bolj množično vključevanje elementov in podatkov kot takšnih, predvsem pa tudi hitrejše delo. Razen upravičenih izjem (naročniki) naj bi tudi v regionalni geografiji podatki in njihovo množično prikazovanje ne bili cilj, temveč le sredstvo za ugotavljanje, razumevanje, tolmačenje in reševanje regionalno-razvojne problematike. Pri tem je terensko delo ena od nujnih sestavin, zlasti raziskovalne regionalne geografije.

Prepoznavnosti Slovenije v svetu bo morala slovenska geografija, podobno kot dokaj uspešno doslej, še nadalje posvečati ustrezno pozornost. Pretežno bolj ali manj regionalnogeografski prikazi Slovenije so nujni zaradi majhnosti teritorija, pa tudi zaradi njenega geografskega položaja, ki so mu v preteklosti rekli tudi 'geostrateški položaj'. Nič od tega se ni spremenilo. Zaradi politične odprtosti Evrope se je 'geostrateškemu' pridružil še gospodarski položaj, s tem pa sta se pomen in funkcija Slovenije v Evropi le še okrepila. Zato bi morala k temu bolj zagnano in odločno pristopiti tudi geografija s svojimi objavami v tujini. Te so bile doslej sicer dobrodošle, vendar preredke, preskromne, marsikdaj preveč lokalno obarvane in namenjene le ozkemu krogu uporabnikov. Na vsak način pa bi bilo potrebno Slovenijo predstaviti tudi v okviru ožjega in širšega sosedstva. Raziskovalno delo bi bilo nujno povezovati tudi s tujimi geografskimi inštitucijami, kot je bilo to v preteklosti zelo uspešno uresničeno na primeru preučevanje rabe tal v Sloveniji (Podgorje pri Kamniku so poznali geografi po vsej Evropi !), v Hercegovini in Srbiji, Porabja na Madžarskem, Maribora, Makedonije, Domžal, občine Ruše, otoka Pašman in morda še kaj. Rezultati takšnega znanstvenoraziskovalnega dela so običajno predstavljeni širši strokovni javnosti in so prispevek $\mathrm{k}$ stroki in $\mathrm{k}$ poznavanju obravnavane dežele.

Za bodočnost slovenske regionalne geografije se vsekakor ni bati. Tudi njene teoretske in še posebej metodološke zadrege bodo zagotovo vse manjše zaradi naglega razvoja, oziroma spreminjanja predmeta njenega zanimanja, pri čemer se tudi vse meje hitro spreminjajo ali 
celo izginjajo. Verjetno tudi v bodoče ne bo prav veliko zanimanja za popolno usmeritev posameznikov v regionalno geografijo; upati je pa vendarle v kakšnega specialista za regionalno geografijo. Zdi se mi, da bi regionalni geografiji močno koristilo ustrezno zanimanje zanjo s strani geografov na vseh obstoječih slovenskih geografskih ustanovah.

\section{Viri in literatura}

Bela krajina in Krajinski park Lahinja. Znanstvena založba Filozofske fakultete, Oddelek za geografijo. Ljubljana 2008.

Brinovec, S., Klemenčič, M. M., Lovrenčak, F., Jeršič, M. 1991: Regionalna geografija sveta. Mladinska knjiga. Ljubljana.

Brinovec, S., Drobnjak, B., Pak, M., Senegačnik, J. 1994: Geografija Evrope. Mladinska knjiga. Ljubljana.

Drozg, V. 2004: Predgovor - o namenu in vsebini publikacije. V: Teorija in praksa regionalizacije Slovenije, str. 5-7. Pedagoška fakulteta Univerze v Mariboru. Maribor.

Drozg, V. 2007: Dejan Rebernik: Urbana geografija. Geografske značilnosti mest in urbanizacije v svetu. Revija za geografijo 2, 2, str. 101-103. Maribor.

Gams, I. 1974: O konceptu geografije za 2. in 3. razred. Geografski obzornik 21, 2-3, str. 7-10. Ljubljana.

Gams, I. 1977: Sedemdesetletnica Svetozarja Ilešiča. Geografski vestnik 49, str. 3-8. Ljubljana.

Gams, I. 1983: Geografske značilnosti Slovenije. Mladinska knjiga. Ljubljana.

Gams, I. 1987: Regionalna geografija v sistemu geografske znanosti. Dela 4, str. 1-13. Ljubljana.

Geografija Ljubljane. Oddelek za geografijo Filozofske fakultete Univerze v Ljubljani. Ljubljana 2002.

Geografija Slovenije. Slovenska matica. Ljubljana 1998.

Geografski atlas Slovenije - država v prostoru in času. DZS. Ljubljana 1998.

Geografski terminološki slovar. Založba ZRC. Ljubljana 2005.

Ilešič, S. 1947: Gospodarska in politična geografija sveta. Državna založba Slovenije. Ljubljana.

Ilešič, S. 1952: Amerika. Državna založba Slovenije. Ljubljana.

Ilešič, S. 1957: Afrika, Južna Azija, Avstralija z Oceanijo in južnim polarnim svetom. Državna založba Slovenije. Ljubljana.

Ilešič, S. 1960: Ob sedemdesetletnici profesorja Antona Melika. Geografski vestnik 32, str. 3-9. Ljubljana.

Ilešič, S. 1966: Evropa s Sovjetsko zvezo. Državna založba Slovenije. Ljubljana.

Ilešič, S. 1969: Regionalna geografija za 3. razred gimnazij in drugih srednjih šol. Mladinska knjiga. Ljubljana.

Ilešič, S. 1973: Regionalna geografija. Evropa s Sovjetsko zvezo. Za 2. razred gimnazij in drugih srednjih šol. Mladinska knjiga. Ljubljana.

Ilešič, S. 1974: Redakcijska zasnova in struktura predvidene regionalno-geografske monografije Slovenije. Geografski vestnik 46, str. 103-114. Ljubljana. 
Ilešič, S. 1975: Regionalna geografija. Bližnji in Srednji vzhod, Monsunska in Notranja Azija, Avstralija in Oceanija, Afrika, Latinska Amerika, Severna Amerika, svet kot celota. Za 3. razred gimnazij in drugih srednjih šol. Mladinska knjiga. Ljubljana.

Ilešič, S. 1979: Pogledi na geografijo. Partizanska knjiga. Ljubljana.

Klemenčič, M. M., Lipovšek, I. 2002: Geografija Slovenije. Učbenik za 3. letnik gimnazij. DZS. Ljubljana.

Klemenčič, M. M., Lampič, B., Potočnik Slavič, I. 2008: Življenjska (ne)moč obrobnih podeželskih območij v Sloveniji. Zbirka GeograFF 3. Znanstvena založba Filozofske fakultete, Oddelek za geografijo. Ljubljana.

Lovrenčak, F. 1987: Regionalna geografija v slovenski geografiji. Dela 4, str. 52-65. Ljubljana.

Marburg/Maribor. Geographische Beiträge über die Partnerstädte in Deutschland und Slowenien. Marburger Geographische Schriften 126. Marburg an der Lahn 1994.

Marburg/Maribor. Geographische Beiträge über die Partnerstädte in Deutschland und Slowenien. Marburger Stadtschriften zur Geschichte und Kultur 48. Marburg an der Lahn 1994.

Maribor/Marburg. Prispevki h geografiji prijateljskih mest v Sloveniji in Nemčiji. Pedagoška fakulteta Univerze v Mariboru. Maribor 1994.

Medved, J. 1969: Afrika. Filozofska fakulteta. Ljubljana.

Medved, J. 1972: Latinska Amerika. Filozofska fakulteta, Ljubljana.

Medved, J. 1973: O novi orientaciji geografije kot učnega predmeta. Geografski obzornik 20, 1-2, str. 22-30. Ljubljana.

Melik, A. 1935: Slovenija. Geografski opis. 1. Splošni del, 1. zvezek. Slovenska matica. Ljubljana.

Melik, A. 1936: Slovenija. Geografski opis. 1. Splošni del, 2. zvezek. Slovenska matica. Ljubljana.

Melik, A. 1948: Jugoslavija. Zemljepisni pregled. Državna založba Slovenije. Ljubljana.

Melik, A. 1954: Slovenija. Geografski opis. II. Opis slovenskih pokrajin, 1. zvezek: Slovenski alpski svet. Slovenska matica. Ljubljana.

Melik, A. 1957: Slovenija. Geografski opis. II. Opis slovenskih pokrajin, 2. zvezek: Štajerska s Prekmurjem in Mežiško dolino. Slovenska matica. Ljubljana.

Melik, A. 1959: Slovenija. Geografski opis. II. Opis slovenskih pokrajin, 3. zvezek: Posavska Slovenija. Slovenska matica. Ljubljana.

Melik, A. 1960: Slovenija. Geografski opis. II. Opis slovenskih pokrajin, 4. zvezek: Slovensko primorje. Slovenska matica. Ljubljana.

Melik, A. 1963: Slovenija. Geografski opis. 1. Splošni del, 2. predelana izdaja. Slovenska matica. Ljubljana.

Natek, K., Natek, M. 1999: Države sveta 2000. Mladinska knjiga. Ljubljana.

Natek, K., Natek, M. 2000: Države svijeta 2000. Mozaik knjiga. Zagreb

Natek, K., Natek, M. 2005: Države sveta. Mladinska knjiga. Beograd.

Natek, K., Natek, M. 2006: Države sveta. Mladinska knjiga. Ljubljana.

Pak, M. 1987 (ur.): Teorija in metodologija regionalne geografije. Jugoslovanski simpozij, Ljubljana, 2. do 3. aprila 1987. Dela 4. Ljubljana. 
Pak, M. 1989: O regionalni geografiji na ljubljanski univerzi. Dela 6, str. 30-39. Ljubljana.

Plut, D. 1989: Ob 70-letnici poučevanja in raziskovanja geografije na ljubljanski univerzi. Dela 6, str. 1-8. Ljubljana.

Pomurje. Geografski pogledi na pokrajino ob Muri. Zveza geografov Slovenije, Društvo geografov Pomurja. Murska Sobota 2009.

Senegačnik, J. 2005: Geografija Evrope v šolskih učbenikih evropskih držav. Doktorska disertacija, Oddelek za geografijo, Filozofska fakulteta Univerze v Ljubljani. Ljubljana.

Senegačnik, J., Lipovšek, I., Pak, M. 2006: Evropa. Geografija za 2. in 3. letnik gimnazij. Modrijan. Ljubljana.

Slovenia. A gateway to Central Europe. Zveza geografskih društev Slovenije. Ljubljana 1996.

Slovenia. A geographical overview. Zveza geografskih društev Slovenije, Založba ZRC. Ljubljana 2004.

Slovenia. Geographic aspects of a new independent European nation. Zveza geografskih društev Slovenije. Ljubljana 1992.

Slowenien. Transformationen und kleinräumige Vielfalt. Natur - Raum - Gesellschaft 5. Institut für Humangeographie. Frankfurt am Main 2008.

Slovenija - pokrajine in ljudje. Mladinska knjiga. Ljubljana 1998.

Spodnje Podravje s Prlekijo. Možnosti regionalnega in prostorskega razvoja. Zveza geografskih društev Slovenije. Ljubljana 1996.

Topole, M. 1998: Mirnska dolina. Regionalna geografija porečja Mirne na Dolenjskem. Založba ZRC. Ljubljana.

Topole, M. 2003: Geografija občine Moravče. Zbirka Geografija Slovenije 7. Založba ZRC. Ljubljana.

Vrišer, I. 1985: Slovenski geografi ob smrti akademika profesorja dr. Svetozarja Ilešiča. Geografski vestnik 57, str. 3-6. Ljubljana.

Wolf, K. 1996: Aufgaben einer zielorientierten geographischen Landeskunde. Geografski vestnik 67, str. 163-168. Ljubljana.

\section{A BRIGHTER FUTURE FOR THE SLOVENE REGIONAL GEOGRAPHY?}

\section{Summary}

Due to its exceptional geopolitical position in the European, and increasingly also in the global space, and due to an exceptional landscape variety at the junction of European macroregions, Slovenia has always been the subject of interest of regional-geographical studies. This was one of the reasons that four extensive and scientifically excellent books on regional geography of Slovenia by A. Melik, as well as many secondary-education and higher-education textbooks by S. Ilešič were published after the Second World War which are still ranked among our greatest achievements in regional geography.

In the 1960s, the Slovene geographers dedicated their dissertations, treating the problems in relation to regional geography, to studying numerous specific Slovene regions. However, 
the interest for a somehow narrower professional orientation prevailed, and regional-geographical studies were thus pushed into the background. The 'crisis of regional geography' initiated lively debates on the theory and methodology of 'modern regional geography', on its applicability and overall necessity. This holds good in particular for school geography which was, within the context of teaching curricula, most frequently the subject of polemics, with a special stress put on the updating of geographical textbooks. Considering their subjectmatter, didactic approach and technical nature, secondary-school as well as elementaryschool textbooks are comparable to those at the international level.

The problems in relation to regional development also forced Slovene geographers to step up the introduction of regional concept in most fields of specialization. However, some people classify geographic studying of ecological problems, rural development, urbanization and suburbanization, and natural disasters among regional-geographical studying. Advanced computer techniques for gathering information concerning regional-geographical issues, and a rapid socio-economic development require the increasingly complex knowledge, tackling, addressing and representation of regional spatial problems. This is also confirmed through ecological problems, economic crisis, political changes, and the related socio-economic changes, including globalization.

After 1991, the interest in regional-geographical issues increased. The regional-geographical concept in the Slovene geography is the subject of extension in particular to numerous research areas, and number of the most significant books were published, such as Geografski atlas Slovenije (Geographical atlas of Slovenia, 1998), Slovenija-pokrajine in ljudje (Slovenia - regions and people, 1998), Geografija Slovenije (Geography of Slovenia, 1998). Among numerous other regional studies, there was also the publication published in Frankfurt am Main Slowenien - Transformationen und kleinräumige Vielfalt (2008). In recent years, Slovene geographical institutions have been publishing the following journals: Geografski vestnik, Acta geographica Slovenica, Dela, Revija za geografijo, and publication series, such as GeograFF (Department of Geography, Faculty of Arts, University of Ljubljana) and Geografija Slovenije (Geography of Slovenia; Anton Melik Geographical Institute).

An increased interest in the Slovene regional geography is expected, being in the field of regional-development issues, recognisability of Slovenia, etc. Greater flexibility is provided in the methodological field. However, the emphasis must be laid on problems, processes and causality, with regional geography becoming even more problem-oriented and targeted.

(Translated by Snežana Pak Dvorak) 